Bangladesh J. Bot. 44(1): 117-123, 2015 (March)

\title{
EFFECTS OF GINKGO BILOBA L. EXTRACT ON THE SEED GERMINATION, SEEDLING GROWTH AND LEAF ANATOMY OF BARLEY UNDER SALINE CONDITIONS
}

\author{
Kürşat ÇAVUŞOĞLU* aNd Şölen Karaferyelì \\ Department of Biology, Faculty of Arts and Science, Süleyman Demirel University, \\ Isparta 32260, Turkey
}

Key words: Barley, Leaf anatomy, Salt stress, Seed germination, Seedling growth

\begin{abstract}
Effects of Ginkgo biloba L. extract on the seed germination, seedling growth and leaf anatomy of barley under saline conditions were studied. In parallel with concentration rise, salt stress inhibited the seed germination and seedling growth of barley. The inhibitive effect of salt on the germination and coleoptile percentage was alleviated in varying degrees, and dramatically, by Ginkgo biloba application. However, it became ineffective in alleviating of salt inhibition on the radicle, coleoptile length, radicle number and fresh weight of barley seedlings. On the other hand, it was observed that Ginkgo biloba extract affected in different degrees the various parameters of leaf anatomy of barley seedlings, and this difference was statistically important.
\end{abstract}

\section{Introduction}

Nearly $20 \%$ of the world's cultivated area and half of the world's irrigated lands are affected by salinity (Zhu 2001). The salt-affected soils contain excess salts which affect plants by decreasing the osmotic potential of the soil solution (osmotic stress), interfering with normal nutrient uptake, inducing ionic toxicity, and associating nutrient imbalances (An et al. 2003). Processes such as seed germination, seedling growth and vigour, vegetative growth, flowering and fruit set are adversely affected by high salt concentration, ultimately causing diminished economic yield and also quality of production (Sairam and Tyagi 2004). In addition, it is evident that there are big changes in leaf morphology and anatomy of the plants growing in saline soils (Çavuşoğlu et al. 2008).

Ginkgo biloba L. (GB) is probably the oldest known tree species, dating back to 300 million years and it is often called the "living fosil" (Mariassyova 2006). More than 20 Ginkgo variations exist that differ in tree habitat and in shape, colour and size of leaves, the latter being the raw material for the pharmaceutical industry (Ellain-Wojtaszek et al. 2002). Especially the leaves of GB contain compounds possessing an antioxidant character (Zahradnikova et al. 2007). There have been isolated three main compounds from GB with an antioxidant activity-kaempferol, quercetin and isoharmnetin (Spence and Jane 1999). The antioxidant activity of a Ginkgo extract is determined mainly by flavonoids, which scavenge and destroy free radicals and the reactive forms of oxygen (Ellain-Wojtaszek et al. 2002). GB leaf extract is the most widely sold phytomedicine in Europe, where it is used to treat the symptoms of early-stage Alzheimer's disease, vascular dementia, premenstrual problems, peripheral claudication, altitude sickness and tinnitus of vascular origin (Sierpina et al. 2003).

Although there are many clinical reports on GB, unfortunately, the protective mechanisms of GB on salt stress in plants are stil poorly understood. The purpose of this study is to observe the influences of GB extract in reducing the inhibitive effects of salt stress on the seed germination, seedling growth and leaf anatomy of barley.

*Author for correspondence: $<$ kursatcavusoglu@sdu.edu.tr>. 


\section{Materials and Methods}

Barley (Hordeum vulgare L. cv. Bülbül 89) seeds were used. Salt $(\mathrm{NaCl})$ concentrations used were $0.0,0.25,0.275$ and $0.30 \mathrm{M}$. Ginkgo biloba (GB) concentration used in the experiments was $0.5 \mathrm{ppm}$.

Germination experiments were carried out at a constant temperature $\left(20^{\circ} \mathrm{C}\right)$, in the dark in an incubator. Barley seeds in adequate amount were pretreated in the beakers containing sufficient amount of distilled water (control, C) or aqueous solution of GB for $24 \mathrm{~h}$ at room temperature. At the end of this pretreatment, the solutions were filtered immediately and the seeds were dried in vacuum (Braun and Khan 1976). Twenty five seeds from every application were arranged into Petri dishes ( $10 \mathrm{~cm}$ diam.) lined by 2 sheets of Whatman No. 1 filter paper moistened with $7 \mathrm{ml}$ of the salt solution. After sowing, Petri dishes were placed into an incubator for germination for 7 days. It was assumed that the radicle should be $10 \mathrm{~mm}$ long for germination. At the end of the 7th day, after determination of the final germination percentages, the coleoptile emergence percentages and radicle numbers were also recorded, and in addition, the fresh weights in $\mathrm{mg} / \mathrm{seedling}$ were determined. All experiments were repeated four times.

The seedlings from the seeds germinated in the incubator at $20^{\circ} \mathrm{C}$ for 7 days were transferred to pots with perlite including $\mathrm{NaCl}$ solutions prepared with Hoagland recipe and were grown in a growth chamber for 20 days. Anatomical sections were taken from the second leaf of 20-day-old seedlings by a microtome, in 6-7 $\mu \mathrm{m}$ thickness. They were examinated under a binocular light microscope (Olympus CX41) at 100 magnification. Stomata and epidermal cells in a 1-mm ${ }^{2}$ unit area were counted to determine the stomatal index. These counts were made both in the lower and upper surfaces of each leaf 10 times as 3 replicates and the averages were calculated. After the determination of the number of stomata and epidermal cells in the leaf unit area, the stomatal index was estimated according to Meidner and Mansfield's (1968) method. Stomata width and length, epidermal cell width and length, leaf thickness and distance between vascular bundles were also determined. Statistical evaluation concerning all parameters was realized by using SPSS program according to DMRT.

\section{Results and Discussion}

Results showed that GB application increased the germination and coleoptile percentage while it decreased the coleoptile length and fresh weight. In addition, it statistically showed the same values as the $\mathrm{C}$ regarding the radicle lenght and radicle number (Table 1). Çavuşoğlu et al. (2010) reported that GB partly reduced the germination percentage of Vicia faba seeds in distilled water medium. This result was not consistent with the present findings. Howewer, they also observed that GB did not show a meaningful effect on the radicle length of $V$. faba seedlings and this is consistent with the present findings. It can be said that GB can show different effects on seed germination and seedling growth depending on the plant species and the concentrations used.

Salt, in the paralellism of concentration increase, increased its inhibitive effect on all the examined growth parameters. For example, while $\mathrm{C}$ seeds germinated in distilled water medium showed $94 \%$ germination on the 7th day, this value became 35,24 and $18 \%$, respectively in 0.25 , 0.275 and $0.30 \mathrm{M}$ salinity (Table 1 ). On the other hand, GB application markedly alleviated the inhibitive effect of salt stress on the seed germination. The seeds pretreated with GB demonstrated 77,65 and $56 \%$ germination in the above mentioned salt levels. GB also continued its success on the coleoptile percentage. However, it was ineffective in alleviating salt inhibition on the radicle length, coleoptile length, radicle number and fresh weight of barley seedlings (Table 1). It is possible that GB may be effective in alleviating the inhibitive effect of salt on the seed germination by increasing nucleic acid and protein synthesis, by stimulating mitotic activity of 
embryo, by providing stabilization of cell membranes or by raising antioxidant enzyme activities (Ellain-Wojtaszek et al. 2002, Zahradnikova et al. 2007).

Table 1. Various growth parameters of the seedlings from barley seeds germinated in saline conditions for 7 days.

\begin{tabular}{cccccccc}
\hline & & \multicolumn{7}{c}{ Growth parameters } \\
\cline { 3 - 7 } $\begin{array}{c}\mathrm{NaCl} \\
(\mathrm{M})\end{array}$ & $\begin{array}{c}\text { Pretreatment } \\
(\mathrm{ppm})\end{array}$ & $\begin{array}{c}\text { Germination } \\
(\%)\end{array}$ & $\begin{array}{c}\text { Coleoptile } \\
(\%)\end{array}$ & $\begin{array}{c}\text { Radicle } \\
\text { length } \\
(\mathrm{mm})\end{array}$ & $\begin{array}{c}\text { Coleoptile } \\
\text { length } \\
(\mathrm{mm})\end{array}$ & $\begin{array}{c}\text { Radicle } \\
\text { number }\end{array}$ & $\begin{array}{c}\text { Fresh } \\
\text { weight } \\
(\mathrm{mg} / \mathrm{seedling})\end{array}$ \\
\hline 0.0 & $\mathrm{C}$ & ${ }^{*} 94 \pm 4.0^{\mathrm{g}}$ & $93 \pm 2.0^{\mathrm{g}}$ & $104.0 \pm 1.7^{\mathrm{d}}$ & $131.9 \pm 2.7^{\mathrm{h}}$ & $4.8 \pm 0.0^{\mathrm{b}}$ & $401.9 \pm 2.7^{\mathrm{h}}$ \\
& $\mathrm{GB}$ & $100 \pm 0.0^{\mathrm{h}}$ & $97 \pm 2.0^{\mathrm{h}}$ & $104.9 \pm 1.4^{\mathrm{d}}$ & $110.7 \pm 1.2^{\mathrm{g}}$ & $4.8 \pm 0.2^{\mathrm{b}}$ & $379.7 \pm 1.2^{\mathrm{g}}$ \\
0.25 & $\mathrm{C}$ & $35 \pm 3.8^{\mathrm{c}}$ & $34 \pm 2.3^{\mathrm{c}}$ & $58.4 \pm 2.0^{\mathrm{c}}$ & $38.4 \pm 1.9^{\mathrm{f}}$ & $4.4 \pm 0.1^{\mathrm{a}}$ & $208.4 \pm 1.9^{\text {ef }}$ \\
& $\mathrm{GB}$ & $77 \pm 2.0^{\mathrm{f}}$ & $75 \pm 2.0^{\mathrm{f}}$ & $55.9 \pm 2.2^{\mathrm{bc}}$ & $35.9 \pm 1.3^{\mathrm{e}}$ & $4.4 \pm 0.2^{\mathrm{a}}$ & $205.9 \pm 1.3^{\mathrm{e}}$ \\
0.275 & $\mathrm{C}$ & $24 \pm 3.2^{\mathrm{b}}$ & $24 \pm 3.2^{\mathrm{b}}$ & $56.0 \pm 2.7^{\mathrm{bc}}$ & $26.0 \pm 2.3^{\text {cd }}$ & $4.4 \pm 0.1^{\mathrm{a}}$ & $196.0 \pm 1.3^{\mathrm{cd}}$ \\
& $\mathrm{GB}$ & $65 \pm 2.0^{\mathrm{e}}$ & $64 \pm 3.2^{\mathrm{e}}$ & $47.0 \pm 1.8^{\mathrm{ab}}$ & $19.9 \pm 1.7^{\mathrm{b}}$ & $4.3 \pm 0.1^{\mathrm{a}}$ & $189.9 \pm 1.7^{\mathrm{b}}$ \\
0.30 & $\mathrm{C}$ & $18 \pm 2.3^{\mathrm{a}}$ & $18 \pm 2.3^{\mathrm{a}}$ & $45.5 \pm 1.7^{\mathrm{ab}}$ & $24.3 \pm 1.4^{\mathrm{c}}$ & $4.3 \pm 0.2^{\mathrm{a}}$ & $194.3 \pm 1.4^{\mathrm{c}}$ \\
& $\mathrm{GB}$ & $56 \pm 3.2^{\mathrm{d}}$ & $53 \pm 3.8^{\mathrm{d}}$ & $44.3 \pm 2.9^{\mathrm{a}}$ & $15.8 \pm 1.0^{\mathrm{a}}$ & $4.2 \pm 0.3^{\mathrm{a}}$ & $182.8 \pm 2.0^{\mathrm{a}}$ \\
\hline
\end{tabular}

*The difference between values with the same letter in each column is not significant at $0.05( \pm \mathrm{SD})$.

GB greatly affected the leaf anatomical structures of Hordeum vulgare seedlings grown under normal conditions (Figs 1, 2 and 3). In distilled water medium, GB pretreatment increased the number, width and length of stomata in the upper surface; the epidermal cell length in the lower surface; the epidermal cell width and stomatal index in both surfaces; and the distance between vascular bundles in comparison with the $\mathrm{C}$ seedlings. GB application reduced the width and length of stomata in the lower surface; the epidermal cell length in the upper surface in comparison with the $\mathrm{C}$ seedlings (Table 2).

Salinity of the medium caused changes in the leaf anatomical characters of seedlings (Figs 1,2 and 3). $0.25 \mathrm{M}$ salinity stimulated the epidermal cell number in the lower surface; the epidermal cell width and epidermal cell length in both surfaces; and the leaf thickness and distance between vascular bundles in the seedlings non-pretreated with GB in compared to $\mathrm{C}$. This salt level decreased the stomata length in the lower surface; the stomata number, stomata width and stomatal index in both surfaces. As for $0.275 \mathrm{M}$ salinity, it increased the epidermal cell width in the upper surface; the epidermal cell number in the lower surface; the epidermal cell length in both surfaces; and the leaf thickness and distance between vascular bundles. This salinity reduced the stomata length in the lower surface; the stomata number, stomata width and stomatal index in both surfaces. $0.30 \mathrm{M}$ salinity increased the epidermal cell number in the lower surface; the epidermal cell width and epidermal cell length in both surfaces; and the leaf thickness and distance between vascular bundles. The mentioned salinity decreased the stomata number, stomata width, stomata length and stomatal index in both surfaces (Table 2). On the other hand, it was reported previously that salt stress caused positive or negative effects on the leaf anatomical parameters of barley seedlings (Çavuşoğlu et al. 2007, 2008). These observations indicate that barley leaves acquire succulent (for example, in the upper surface the increase in epidermal cell width; in the lower surface the decrease in stomata number) properties (Strogonov 1964). 

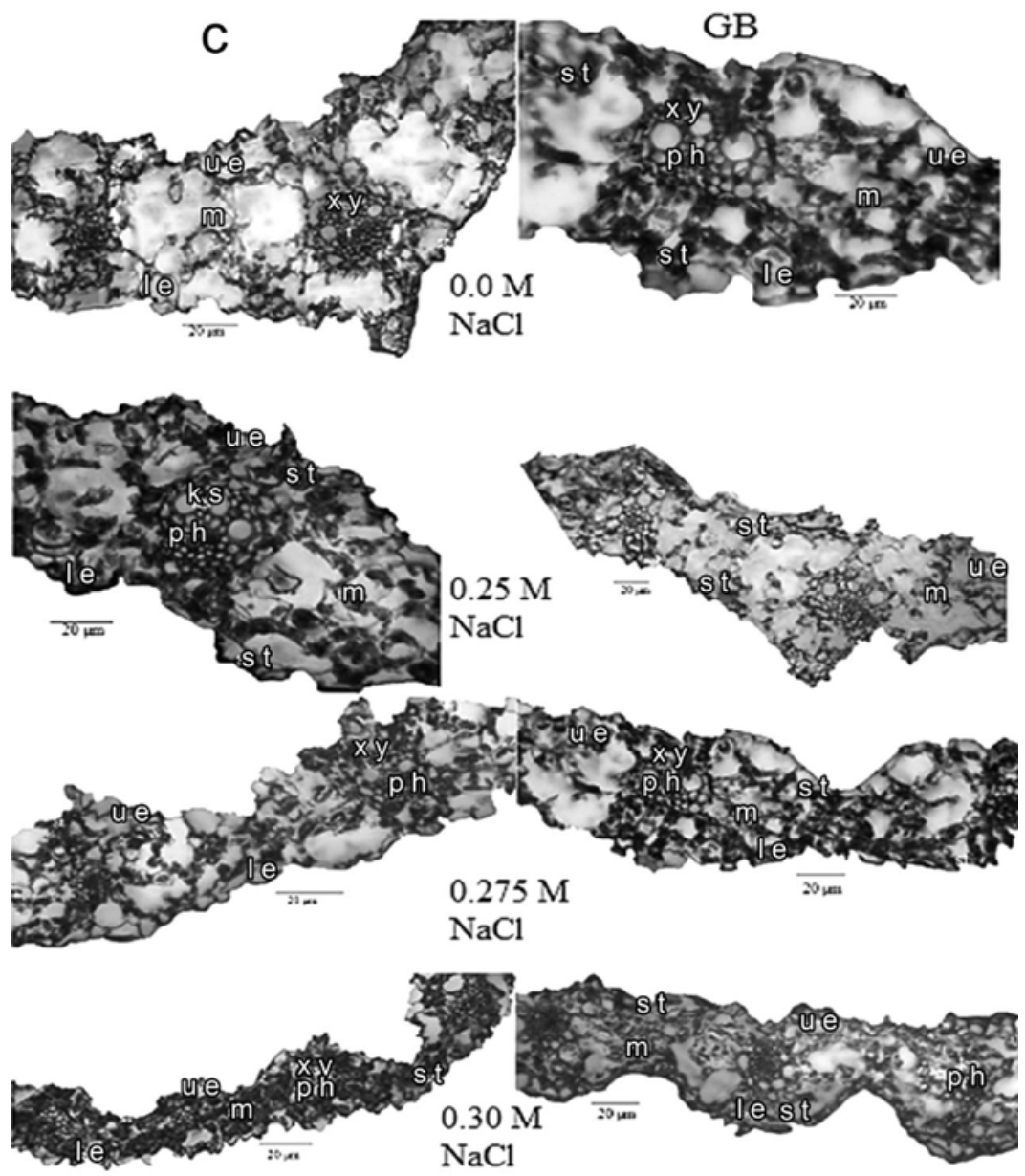

Fig. 1. Leaf cross sections from distilled water and GB pretreated barley seedlings grown in various concentrations of $\mathrm{NaCI}$ at $25^{\circ} \mathrm{C}$ (le: lower epidermis, ue: upper epidermis, m: mesophyll, st: stomata, xy: xylem, ph: floem).

GB pretreatment increased the stomata width in the upper surface; the epidermal cell length in the lower surface; the stomata number, stomata length and stomatal index in both surfaces; and the leaf thickness in comparison with the $\mathrm{C}$ seedlings grown in $0.25 \mathrm{M}$ salinity. This pretreatment reduced the epidermal cell length in the upper surface; the epidermal cell number and epidermal cell width in the lower surface; and the distance between vascular bundles. In $0.275 \mathrm{M}$ salinity, GB application increased the stomata number, stomata width, stomata length and stomatal index in both surfaces. This application decreased the epidermal cell number in the lower surface; the epidermal cell width and epidermal cell length in both surfaces; and the leaf thickness and distance between vascular bundles. As for $0.30 \mathrm{M}$ salinity, GB increased the epidermal cell number in the upper surface; the stomata number, stomata width, stomata length and stomatal index in both surfaces. It reduced the epidermal cell number in the lower surface; the epidermal cell width and epidermal cell length in both surfaces; and the leaf thickness and distance between vascular bundles (Table 2). 


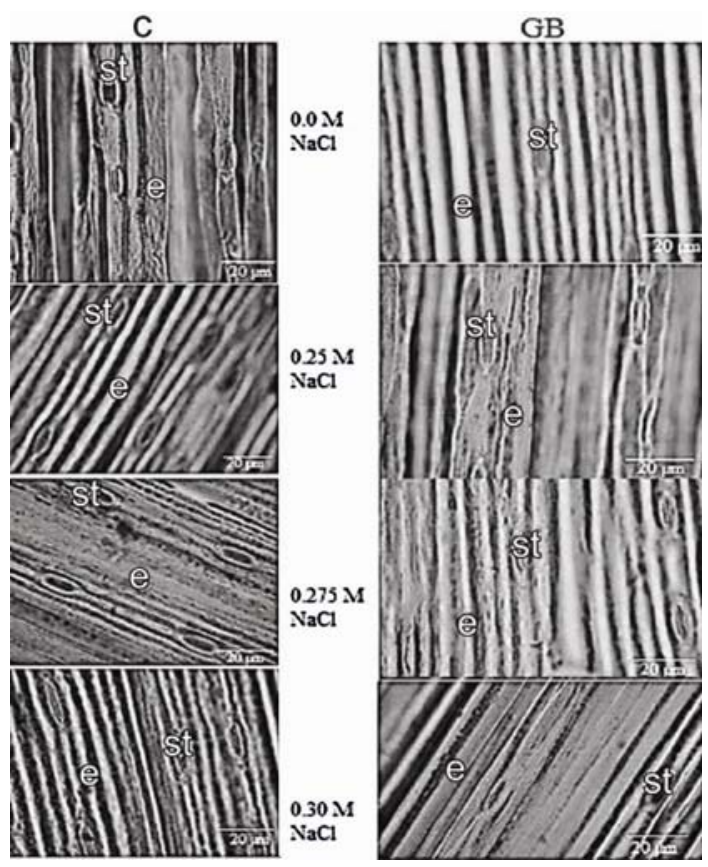

Fig. 2. Leaf lower surface sections from distilled water and GB pretreated barley seedlings grown in various concentrations of $\mathrm{NaCI}$ at $25^{\circ} \mathrm{C}$ (e: epidermis, st: stomata).

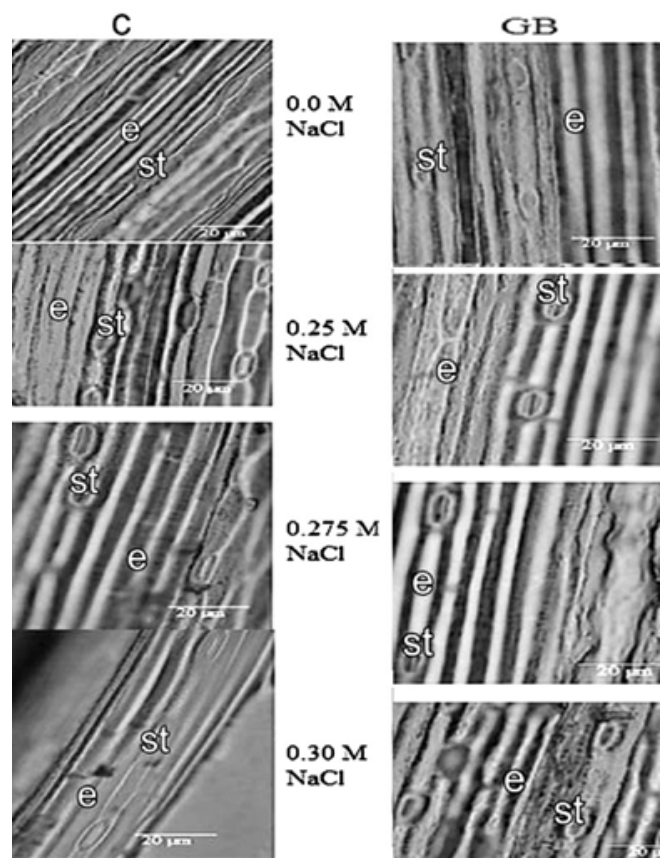

Fig. 3. Leaf upper surface sections from distilled water and GB pretreated barley seedlings grown in various concentrations of $\mathrm{NaCI}$ at $25^{\circ} \mathrm{C}$ (e: epidermis, st: stomata). 
GB pretreatment makes water and food transport easy by reducing the distance between vascular bundles in $0.25,0.275$ and $0.30 \mathrm{M} \mathrm{NaCl}$. Moreover, the mentioned application provides adaptation to saline conditions by increasing the leaf thickness in $0.25 \mathrm{M}$ salinity and so decrease transpiration and water loss. In addition, it can lead to the same aim by causing a reduction of leaf area as a result of decreasing epidermal cell width and epidermal cell length of both surfaces of the leaves in all the salt levels.

Table 2. Some parameters of leaf anatomy of barley seedlings grown for 20 days in various concentrations of $\mathrm{NaCl}$ at $25^{\circ} \mathrm{C}$ after GB pretreatment.

\begin{tabular}{|c|c|c|c|c|c|c|c|c|c|}
\hline \multirow[t]{2}{*}{$\begin{array}{c}\mathrm{NaCl} \\
(\mathrm{M})\end{array}$} & \multirow{2}{*}{$\begin{array}{c}\text { Pre- } \\
\text { treatment } \\
(\mathrm{ppm})\end{array}$} & \multicolumn{2}{|c|}{$\begin{array}{l}\text { Epidermal } \\
\text { cell number }\end{array}$} & \multicolumn{2}{|c|}{$\begin{array}{c}\text { Epidermal } \\
\text { cell width }(\mu \mathrm{m})\end{array}$} & \multicolumn{2}{|c|}{$\begin{array}{c}\text { Epidermal } \\
\text { cell length }(\mu \mathrm{m})\end{array}$} & \multicolumn{2}{|c|}{$\begin{array}{l}\text { Stomata } \\
\text { number }\end{array}$} \\
\hline & & Upper & Lower & Upper & Lower & Upper & Lower & Upper & Lower \\
\hline \multirow[t]{2}{*}{0.0} & $\mathrm{C}$ & $* 11.8 \pm 2.1^{\mathrm{a}}$ & $9.1 \pm 2.2^{b}$ & $8.7 \pm 1.3^{\mathrm{a}}$ & $9.2 \pm 1.2^{\mathrm{ab}}$ & $25.0 \pm 2.3^{\mathrm{ab}}$ & $24.7 \pm 1.8^{\mathrm{a}}$ & $5.7 \pm 1.1^{\mathrm{e}}$ & $5.1 \pm 1.0^{\mathrm{d}}$ \\
\hline & GB & $10.5 \pm 2.2^{\mathrm{a}}$ & $9.0 \pm 2.0^{\mathrm{b}}$ & $10.2 \pm 1.8^{\mathrm{b}}$ & $10.7 \pm 1.6^{\mathrm{b}}$ & $24.0 \pm 2.1^{\mathrm{a}}$ & $28.5 \pm 1.0^{\mathrm{bc}}$ & $8.2 \pm 2.1^{\mathrm{f}}$ & $5.0 \pm 1.0^{\mathrm{d}}$ \\
\hline \multirow[t]{2}{*}{0.25} & $\mathrm{C}$ & $11.5 \pm 1.3^{\mathrm{a}}$ & $11.2 \pm 1.4^{\mathrm{c}}$ & $10.0 \pm 1.6^{\mathrm{b}}$ & $10.5 \pm 1.9^{b}$ & $29.2 \pm 2.4^{\mathrm{c}}$ & $29.7 \pm 1.1^{\mathrm{c}}$ & $3.6 \pm 1.1^{\mathrm{bc}}$ & $3.8 \pm 1.1^{\mathrm{b}}$ \\
\hline & GB & $10.4 \pm 2.3^{\mathrm{a}}$ & $8.3 \pm 1.7^{\mathrm{a}}$ & $10.0 \pm 1.6^{\mathrm{b}}$ & $9.2 \pm 1.6^{\mathrm{ab}}$ & $26.2 \pm 1.1^{\mathrm{b}}$ & $30.2 \pm 1.4^{\mathrm{d}}$ & $5.2 \pm 1.4^{\mathrm{de}}$ & $4.3 \pm 1.1^{\mathrm{c}}$ \\
\hline \multirow[t]{2}{*}{0.275} & $\mathrm{C}$ & $10.6 \pm 1.4^{\mathrm{a}}$ & $14.0 \pm 1.6^{\mathrm{d}}$ & $10.0 \pm 1.6^{\mathrm{b}}$ & $9.5 \pm 2.2^{\mathrm{ab}}$ & $29.2 \pm 1.1^{\mathrm{c}}$ & $29.2 \pm 2.4^{\mathrm{c}}$ & $3.4 \pm 0.9^{\mathrm{ab}}$ & $3.2 \pm 0.7^{\mathrm{a}}$ \\
\hline & GB & $11.0 \pm 2.0^{\mathrm{a}}$ & $8.1 \pm 1.6^{\mathrm{a}}$ & $9.2 \pm 1.6^{\mathrm{ab}}$ & $8.5 \pm 1.2^{\mathrm{a}}$ & $24.2 \pm 1.0^{\mathrm{a}}$ & $25.0 \pm 1.3^{\mathrm{a}}$ & $4.4 \pm 1.1^{\mathrm{cd}}$ & $3.6 \pm 0.6^{\mathrm{ab}}$ \\
\hline \multirow[t]{2}{*}{0.30} & $\mathrm{C}$ & $11.7 \pm 1.9^{\mathrm{a}}$ & $14.9 \pm 2.3^{\mathrm{d}}$ & $9.2 \pm 2.0^{\mathrm{ab}}$ & $11.0 \pm 2.4^{\mathrm{b}}$ & $26.2 \pm 1.7^{b}$ & $27.0 \pm 2.3^{\mathrm{b}}$ & $2.6 \pm 0.7^{\mathrm{a}}$ & $3.2 \pm 0.7^{\mathrm{a}}$ \\
\hline & GB & $13.7 \pm 2.2^{\mathrm{b}}$ & $8.1 \pm 1.9^{\mathrm{a}}$ & $8.7 \pm 2.1^{\mathrm{a}}$ & $8.2 \pm 2.0^{\mathrm{a}}$ & $24.7 \pm 1.7^{\mathrm{a}}$ & $24.5 \pm 1.2^{\mathrm{a}}$ & $4.7 \pm 1.0^{\mathrm{d}}$ & $4.4 \pm 0.9^{c}$ \\
\hline
\end{tabular}

Table contd. (right side)

\begin{tabular}{|c|c|c|c|c|c|c|c|}
\hline \multicolumn{2}{|c|}{$\begin{array}{l}\text { Stomata width } \\
\qquad(\mu \mathrm{m})\end{array}$} & \multicolumn{2}{|c|}{$\begin{array}{l}\text { Stomata length } \\
\qquad(\mu \mathrm{m})\end{array}$} & \multicolumn{2}{|c|}{$\begin{array}{l}\text { Stomatal } \\
\text { index }\end{array}$} & \multirow{2}{*}{$\begin{array}{l}\text { Leaf } \\
\text { thickness } \\
\qquad(\mu \mathrm{m})\end{array}$} & \multirow{2}{*}{$\begin{array}{c}\text { Distace between } \\
\text { vascular bundles } \\
\qquad(\mu \mathrm{m})\end{array}$} \\
\hline Upper & Lower & Upper & Lower & Upper & Lower & & \\
\hline $13.5 \pm 1.7^{b}$ & $16.5 \pm 3.1^{\mathrm{d}}$ & $38.1 \pm 2.6^{b}$ & $47.1 \pm 4.2^{\mathrm{c}}$ & 34.2 & 34.0 & $67.8 \pm 1.3^{b}$ & $122.7 \pm 1.2^{\mathrm{a}}$ \\
\hline $15.8 \pm 2.1^{\mathrm{c}}$ & $14.2 \pm 2.0^{\mathrm{c}}$ & $41.1 \pm 3.3^{c}$ & $41.8 \pm 4.1^{b}$ & 40.8 & 36.2 & $68.1 \pm 2.3^{b}$ & $154.8 \pm 2.6^{\mathrm{e}}$ \\
\hline $12.7 \pm 1.6^{\mathrm{ab}}$ & $14.2 \pm 2.0^{\mathrm{c}}$ & $38.3 \pm 2.3^{b}$ & $37.3 \pm 1.8^{\mathrm{a}}$ & 23.7 & 26.5 & $76.3 \pm 2.1^{\mathrm{d}}$ & $161.0 \pm 2.0^{\mathrm{f}}$ \\
\hline $17.8 \pm 2.5^{\mathrm{d}}$ & $14.6 \pm 1.4^{\mathrm{c}}$ & $40.6 \pm 3.9^{c}$ & $47.8 \pm 4.9^{\mathrm{c}}$ & 32.7 & 33.2 & $93.1 \pm 1.7^{\mathrm{f}}$ & $148.7 \pm 1.0^{\mathrm{c}}$ \\
\hline $11.7 \pm 2.1^{\mathrm{a}}$ & $11.8 \pm 1.9^{\mathrm{ab}}$ & $37.5 \pm 2.2^{\mathrm{b}}$ & $38.0 \pm 2.2^{\mathrm{a}}$ & 21.1 & 18.4 & $78.5 \pm 1.8^{\mathrm{e}}$ & $167.1 \pm 1.8^{\mathrm{g}}$ \\
\hline $18.6 \pm 2.2^{\mathrm{de}}$ & $16.1 \pm 1.5^{\mathrm{d}}$ & $41.1 \pm 3.2^{\mathrm{c}}$ & $41.8 \pm 4.3^{b}$ & 28.8 & 29.7 & $75.0 \pm 1.4^{\mathrm{d}}$ & $155.3 \pm 1.4^{\mathrm{e}}$ \\
\hline $12.2 \pm 1.9^{\mathrm{ab}}$ & $11.2 \pm 1.7^{\mathrm{a}}$ & $35.3 \pm 1.6^{\mathrm{a}}$ & $36.1 \pm 2.3^{\mathrm{a}}$ & 19.0 & 16.5 & $70.2 \pm 1.0^{\mathrm{c}}$ & $150.7 \pm 2.9^{\mathrm{cd}}$ \\
\hline $19.8 \pm 2.2^{\mathrm{e}}$ & $12.7 \pm 1.7^{\mathrm{b}}$ & $42.2 \pm 4.3^{c}$ & $43.3 \pm 4.4^{b}$ & 25.7 & 35.2 & $65.9 \pm 2.2^{\mathrm{a}}$ & $135.5 \pm 2.6^{\mathrm{b}}$ \\
\hline
\end{tabular}

*The difference between values with the same letter in each column is not significant at $0.05( \pm \mathrm{SD})$.

It is clear that adverse effects of salt stress on the seed germination, seedling growth and leaf anatomy of barley were significantly improved by exogenous application of GB. The mechanisms by which salinity inhibits growth are complex and controversial. Moreover, they may vary according to species and cultivar. A universal mechanism has not been established yet. Although the causes of salinity have been characterized, our understanding of the mechanisms by which salinity prevents plant growth is still rather poor. This work may serve to provide new conceptual tools for designing hypotheses of salt tolerance in plants. 


\section{References}

An P, Inanaga S, Li X, Schimizu H and Tanimoto E 2003. Root characteristics in salt tolerance. Root Res. 12: $125-132$.

Braun JW and Khan AA 1976. Alleviation of salinity and high temperature stress by plant growth regulators permeated into lettuce seeds via acetone. J. Am. Soc. Hort. Sci. 101: 716-721.

Çavuşoğlu K, K1lıç S and Kabar K 2007. Some morphological and anatomical observations during alleviation of salinity $(\mathrm{NaCl})$ stress on seed germination and seedling growth of barley by polyamines. Acta Physiol. Plant 29: 551-557.

Çavuşoğlu K, Kılıç S and Kabar K 2008. Effects of some plant growth regulators on leaf anatomy of radish seedlings grown under saline conditions. J. App. Biol. Sci. 2: 47-50.

Çavuşoğlu K, Yapar K, Kınalığlu K, Türkmen Z, Çavuşoğlu K and Yalçın E 2010. Protective role of Ginkgo biloba on petroleum wastewater-induced toxicity in Vicia faba L. (Fabaceae) root tip cells. J. Environ. Biol. 31: 319-324.

Ellain-Wojtaszek M, Krucynski Z and Kasprzak J 2002. Variations in free radical scavenging activity of Ginkgo biloba leaves in the period of complete development of green leaves to fall of yellow ones. Food Chem. 79: 79-84.

Mariassyova M 2006. Antioxidant activity of some herbal extracts in rapeseed and sunflower oils. J. Food Nutr. Res. 45: 104-109.

Meidner H and Mansfield TA 1968. Physiology of stomata. Mc Graw-Hill, New York.

Sairam RK and Tyagi A 2004. Physiology and molecular biology of salinity stress tolerance in plants. Curr. Sci. 86: 407-721.

Sierpina VS, Wollschlaeger B and Blumenthal M 2003. Ginkgo biloba. Am. Acad. Fam. Physic. 68: 923-926.

Spence KE and Jane J 1999. Chemical and physical properties of Ginkgo starch. Carbohyd. Polym. 40: 261269.

Strogonov BP 1964. Physiological basis of salt tolerance of plants. Israel Program for Scientific Translations, S. Monson, Jerusalem.

Zahradnikova L, Schmidt S, Sekretar S and Janac L 2007. Determination of the antioxidant activity of Ginkgo biloba leaves extract. J. Food Nutr. Res. 1: 15-19.

Zhu JK 2001. Over expression of a delta-pyrroline-5-carboxylate synthetase gene and analysis of tolerance to water and salt stress in transgenic rice. Tr. Plant Sci. 6: 66-72.

(Manuscript received on 24 July, 2014; revised on 2 September, 2014) 